\title{
Kuşakların Helal Gıda Satın Alma Niyetlerinin Planlı Davranış Teorisi Bağlamında İncelenmesi: Samsun- Köln Örneği ${ }^{1}$
}

\author{
DOI: $10.26466 /$ opus.862678
}

*

\author{
Mustafa Kemal Y1lmaz * - İsmail Can Albayrak ** \\ * Doç. Dr., Samsun Üniversitesi , İktisadi İdari ve Sosyal Bilimler Fakültesi, Samsun/Türkiye \\ E-Posta: mustafa.yilmaz@samsun.edu.tr \\ ORCID: 0000-0002-6906-5414 \\ ** Uzm., Samsun Üniversitesi, LEE, Samsun/Türkiye \\ E-Posta: icanalbayrak@outlook.com \\ ORCID: $\quad$ 0000-0001-6872-5508
}

Öz

Günümüzde Dünya üzerinde farklı din, dil, ırka sahip milyarlarca insan yaşamaktadır. Aynı zaman diliminde dünyaya gelmiş, benzer durumları tecrübe etmiş, dönemin büyük olaylarına şahit olmuş insan toplulukları kuşak kavramını oluşturmuştur. Kuşak olarak ayrilan insanlar, bir gruba dahil olmalarına rağmen tamamen ayn davranışları sergilediği söylenemez. Bu kuşak grupları farklı dine, cinsiyete, milliyete sahiptirler ve bu konularda birbirlerinden farkllaşmaktadır. Bilhassa din bakımından oluşan bu farklılıklar insanların tüketim davranışlarını da farklılaştırmaktadır. Müslümanlar her ne kadar farklı kuşaklara mensup olsalar da tüketim açısından Allah'ın emir ve yasaklarına uymak durumundadırlar. Müslümanların farklı inanıştaki ülkelere göç ederek Dünya geneline yayılması ve sayılarının gittikçe artması onları helal konusunda daha hassas hale getirmiştir. Özellikle gıda konusunda tüketiciler ürünlerin helalliğini sorgulamaya başlamışlardır. Bunun sonucunda helal ürün pazarları gelişim göstermiştir. Bu çalışmada, Samsun ve Köln'de yaşayan farkl kuşaklara mensup Türk tüketicilerin helal satın alma niyetlerine etkisi olan faktörler incelenmiştir. Bununla birlikte iki ülke arasında kuşak bazında farklılıklar incelenmiştir. $R$ programı kullanılarak uygulanan Yapısal Eşitlik Modeli (YEM) ile model testi, güvenilirlik analizi uygulanmıştır. Çalışma sonunda Samsun ve Köln'de yaşayan tüketicilerin dindarliklarının, algılanan davranışsal kontrollerinin, helal gıdaya yönelik tutumlarınn, helal farkındalıklarını ve öznel normlarımn helal gıda satın alma niyeti üzerinde pozitif ve yüksek derecede etkili olduğu sonucuna ulaşılmıştır.

Anahtar Kelimeler: Helal Gıda, Kuşaklar (X, Y, Z), Helal Gıda Satın Ama Niyeti, Dindalık

\footnotetext{
${ }^{1}$ Bu çalışma Doç. Dr. Mustafa Kemal Yılmaz danışmanlı̆ı̆nda ismail Can Albayrak tarafından 29.12.2020 tarihinde tamamlanan 10372362 nolu yüksek lisans tezinden türetilmiştir.
} 
ISSN:2528-9527

E-ISSN: 2528-9535

Yıl Year: 11

Cilt Volume: 18

Sayı Issue :40

Uluslararası Toplum Araştırmaları Dergisi

International Journal of Society Researches

Ağustos August 2021

Makalenin Geliş Tarihi Received Date: 16/01/2021

Makalenin Kabul Tarihi Accepted Date: 05/03/2021

\title{
An Investigation of the Intentions of Generations $X, Y$ and $\mathrm{Z}$ to Buy Halal Certified Foods: The Sample of Samsun-Köln
}

$*$

\begin{abstract}
In today's world, there are billions of people who have different religions, languages, and nationalities all around the globe. People who were born during the same time periods, who experienced similar situations at the times they lived and who witnessed the great events of the time, have formed the notion of generation. However, these people, who are separated from each other with respect to the factor of generation, cannot be thought to exhibit exactly the same behaviours though they belong to a specific group. These groups of generations have different religions, genders, and nationalities, and they differ from each other in these respects. These differences, especially about the notion of religion, differentiate the behaviours of consumption of people. Muslims, though they may vary in terms of diverse generations, are supposed to obey the orders and restrictions of God considering the fact of consumption. Muslims' migrating to other countries of different religious beliefs, spreading all over the world, and the increase in their population have made them more sensitive about the issue of halal. Consumers have started to question products whether they are halal or not, particularly regarding food and nourishment. As a result, markets of halal products have considerably developed.
\end{abstract}

Keywords: Halal Food, Generations (X, Y And Z), The Intention of Buying Halal Food, Devoutness. 


\section{Giriş}

Dünya nüfusunun yaklaşık 1,9 milyarlık kısmını Müslümanlar oluşturmaktadır. Müslümanların sürekli artan nüfusu, Dünya geneline yayılmaları gibi durumlar, ticaretin de ülke sınırlarını aşıp küresel düzeyde seyretmesi gibi gelişmelerle birleşince Müslümanlar tarafından helal-haram kavramı gündeme gelmiş ve kendi ihtiyaçlarını kendi din ve inanışlarına göre temin etme isteği yeni pazarlar oluşmasına zemin hazırlamıştır.

Helal kavramı, Arapça kökenli olup izin verilen, İslami yasalara uygun olan, haram karşıtı anlamına gelen bir kavramdır (Türk Dil Kurumu, 2020). Helal gida; İslami kurallara uygun olarak izin verilen gıda anlamına gelmektedir. Herhangi bir gıdanın helal özelliği taşıması için öncelikle İslami kurallara göre yasak unsurlar içermemesi, bu unsurlardan arındırılmış mekânlarda ve cihazlarda hazırlanmış, işlenmiş ve depolanmış olması, açıklanan bu unsurların dışında üretimi yapılan herhangi bir gida ürünü ile üretimin farklı aşamalarında direkt bir şekilde temas etmemiş olması gerekmektedir (Kızgın ve Özkan, 2014, s.20). Helal gıda konusu Müslüman tüketiciler arasında en hayati konulardan birisidir. Bu nedenle helal kavramı İslam ülkelerinde çoğu gıda endüstrisi tarafından benimsenmiştir. Ancak günümüzde helal kavramı sadece İslam ülkelerindeki tüketiciler için değil, Müslümanların azınlıkta olduğu ülkelerde de önem kazanmaktadır (Pradana vd., 2020'a, s.1). Müslüman olmayan kesimin helal ürünleri tercih etmesinin ana nedenleri arasında ürünün temiz, hijyenik ve sağlıklı olması gelmektedir (Ahmadova ve Aliyev, 2020, s.56).

Müslümanlar, tükettikleri gıdaların helal veya haram olma durumunu Genel Kur'an rehberliğinde değerlendirirler. Ancak günümüz şartlarında ürün segmentinin aşırılaşması ile birlikte tüketilen gıdaların içeriği konusunda yaşanan kaygılar neticesinde Müslümanlar helal gida konusunda çalışmalar yapmaya başlamışlardır. Müslümanların helal gıda tüketimine dair kaygılarını gidermek amacıyla helal sertifikasyonu oluşturulmuştur (Tatlı vd., 2017, s.39). Helal sertifikası; tanınmış ve yetkin bir kurumun üretici işletmelerin yapmış oldukları faaliyetleri denetleyip ürünlerin İslami açıdan tüketime uygun 
olduğunu taahhüt edip işletmelere vermiş oldukları onay belgesidir (Akbulut vd, 2019, s.111).

Pew Araştırma Enstitüsü tahminlerine göre, 21 Ocak 2017 itibariyle, dünyada yaklaşık 1,8 milyar Müslüman yaşamaktadır. Bu rakam bugün dünya nüfusunun yaklaşık dörtte birini oluşturmaktadır. Pew Araştırma Enstitüsü, 2070 yılına kadar Müslümanların dünyanın en büyük dini grubu haline gelmesinin beklendiğini tahmin etmektedir (Huda, 2017). Müslüman nüfusunun giderek artması ile birlikte küresel helal gida pazarının 2019'a kadar 3,7 trilyon ABD Doları'na ve 2030'a kadar 10 trilyon ABD Doları'na yükselmesi beklenmektedir. Bu eğilimi takiben, dünyanın dev perakende işletmeleri Albert Heijn ve Carrefour, ürün çeşitlerine helal eti eklemişlerdir. Benzer şekilde, McDonalds ve KFC gibi dünyanın önde gelen fast-food markaları, gıda kategorilerinde helal gıda çeşitlerini tanıtmışlardır. Tüm bu gelişmeler, işletmelerin mevcut ürün portföylerini artan Müslüman nüfusun taleplerine göre helal gıdaya geçiş yaptıklarını göstermektedir. İşletmeler için helal gıda pazarı göz ardı edilemeyecek kadar hızlı bir büyüme içerisindedir ve bu büyüme birçok işletme için pazar fırsatı oluşturmaktadır (Sherwani vd., 2018, s.864).

Dünya, yaşamın başlamasından günümüze kadar pek çok değişim geçirmiştir. Çağlar açılmış çağlar kapanmış ve sürekli bir gelişim içerisinde olmuştur. Gelişen dünya ile birlikte insan davranışları da belirli şekiller almaya başlamıştır. Aynı dönemde yaşayan insanlar birbirleri ile aynı davranışları sergilemeye başlamışlar ve kuşak kavramı şekillenmeye başlamıştır. Kuşak kavramı; Doğdukları yıl itibarıyla ekonomik, sosyal ve politik gibi benzer olayları yaşayan, eşsiz değer yargıları ve inanç sistemlerini bünyelerinde geliştiren, kişilik özellikleri birbirleri ile benzer olan bireylerin oluşturduğu bir topluluktur (Aka, 2018, s.120). Kuşaklar her ne kadar insanlığın başlamasından beri var olsa da daha çok son yüzyıl içerisinde araştırılıp sınıflandırılmaya başlanmıştır. Genellikle sosyolojik açıdan incelenen kuşaklar zamanla birçok dalda incelenmiştir. Kuşaklar pazarlama alanında firmaların hedef kitlelerini belirlemesine olanak sağlamıştır ve bu sayede pazarlama çalışmalarını bu ölçüde şekillendirmişlerdir. Genel olarak kuşaklar beş bölümden oluşmaktadır. Ancak biz bu çalışmada sadece $X$, $\mathrm{Y}$ ve $\mathrm{Z}$ kuşaklarını inceleyeceğiz. Günümüz toplumlarında genellikle bu 
üç kuşak daha çok bir arada yaşadığı ve etkileşim içinde olduğundan dolayı alınmıştır.

X Kuşağı, 1965-1979 yılları arasında doğmuş ve demografik açıdan benzerlik gösteren insanların oluşturduğu kuşaktır. X kuşağı, topluma karşıt yapıya sahip, sert politik çıkışları olan, kendine has giyim stili ortaya koyan ve sert müzik anlayışı ve punk yaşam tarzına sahip bir nesildir. Bu neslin bireyleri aşırı sosyalleşme ve para, saygın bir statü ile kendi varoluşlarını açılamaya çalışmaktadırlar (Akdemir ve Konakay, 2013, s.15). Tüketici profili olarak bakıldığında X kuşağı daha çok ebeveyn grubundadır ve harcamalarının bir bölümünü ailesine ayırmaktadır. Bu nesil bilinçli bir tüketicidir ve fiyatlandırma konusunda oldukça hassastırlar (William ve Page, 2011, s.7).

Y Kuşağı, 1980-1999 yılları arasında dünyaya gelen insanlardan oluşan kuşaktır. Y kuşağı genel olarak, bencil, bağımsız, işbirlikçi, çeşitlilik içeren ve kendine güvenen bir kuşaktır. Bu kuşak teknolojinin geliştiği yıllarda ortaya çıarak onunla birlikte büyümüştür ve bu yüzden kendi ebeveynlerinden farklılık gösterirler. Tüketim potansiyelleri oldukça yüksek bir gruptur. Ürünleri deneyimledikten sonra satın alma kararlarını verirler (William ve Page, 2011, s.8). Beklentileri üst seviyededir, risk almayı göze alırlar ve verimlilik açısından etkin olduklarını düşünürler (Sarı ve Harta, 2018, s.969).

Z Kuşağı, 2000 yılından sonra doğan bireylerin oluşturduğu kuşaktır. Bu kuşağın Y kuşağı ile çok fazla ortak noktaları vardır. Kristal Kuşak, internet kuşağı veya google kuşağı gibi isimlerle de adlandırılmaktadır. $\mathrm{Z}$ kuşağı, teknolojinin içine doğmuş bir kuşaktır. Bu durum $\mathrm{Z}$ kuşağının en belirgin özelliğidir. Ayrıca teknolojinin ve teknolojik cihazların kullanımı konusunda aşırı derecede iyilerdir (Dölekoğlu vd., 2018, s.57).

Günümüzde Müslüman kesim ebeveynlerinden ve daha önceki nesillerinden daha eğitimli ve daha varlıklıdırlar. Genç Müslümanlar buna bağlı olarak kozmopolit tüketim kültürüne katılmaya isteklidirler. Küresel Müslüman nüfusunun \%43'ünü ve Dünya nüfusunun \%11'ini temsil eden genç Müslümanlar günümüz teknolojik ürünlerinin yoğun kullanıcılarıdırlar. Aynı zamanda genç Müslüman tüketiciler, tercih ettiği markaları statü sağlama aracı olarak görmektedirler. (Izberk-Bilgin ve Nakata, 2016, s.286). 


\section{Literatür}

Müslümanların nüfus yoğunluğunun artması ve bilinçlenmeleri ile birlikte helal alanında yapılan çalışmalar artış göstermiştir. Kuşakların helal sertifikalı ürünleri satın alma niyetlerinin incelenmesi üzerine yapılmış bazı araştırmalar aşağıdaki gibidir:

Ibrahim ve Ismail (2015)'in yapmış olduğu çalışmada Malezya'da yaşayan $Y$ kuşağı tüketicilerinin dini inanç yoğunluklarının helal etiketi taşıyan kozmetik ve temizlik malzemeleri gibi gıda dışı ürünleri satın alma niyetleri üzerindeki etkisi incelenmiştir. Bu kapsamda 300 kişiye anket uygulanmıştır. Yapılan betimsel ve istatistiksel analizler sonucunda dindarlık ile helal satın alma niyeti arasında anlamlı bir ilişki olduğu görülmüştür.

Khalek ve Ismail (2015) tarafından yapılan çalışmada Planlı Davranış Teorisi modelinden faydalanılarak Malezya'da yaşayan $Y$ kuşağının helal gida tüketiminin incelenmesi amaçlanmıştır. Yapılan analizler sonucunda helal gıdaya yönelik tutumun helal gida tüketme niyetini etkileyen en önemli faktör olduğu saptanmıştır. Bununla birlikte aile, iş ve arkadaş çevresinin helal gıda tüketme niyetleri üzerinde etkili olduğu görülmüştür. Bu durum öznel normların da helal gida tüketme niyetlerini etkilediğini göstermektedir. Üçüncü bir faktör olan algılanan davranış kontrolü ürünün bulunabilirliği ve fiyatı açısından helal gıda tüketme niyetini etkilemektedir.

Yüksekbilgili (2016) tüketicilerin karar verme tarzlarını incelediği çalışmasında $\mathrm{X}$ ve $\mathrm{Y}$ kuşakları arasındaki farklılıkları araştırmıştır. Çalışma sonucunda fiyat odaklılık açısından $X$ kuşağının daha duyarlı olduğu, Y kuşağının ise moda odaklılığına daha çok önem verdiği görülmüştür.

Asif vd. (2018) Türkiye, İran ve Pakistan'daki tüketiciler üzerinde gerçekleştirdiği çalışmada organik gıda satın alma niyetlerini etkileyen faktörleri Planlı Davranış Teorisi aracılığıyla incelemiştir. Çalışmada tutum ve öznel normların her üç ülkede de organik gıda satın alma niyetlerini etkilediği görülmüştür. Algılanan davranışsal kontrolün ise Türkiye'de etkili iken İran ve Pakistan'da etkili olmadığı sonucuna ulaşılmıştır. 
Aşık'ın (2019) yapmış olduğu çalışmada $X$ ve $Z$ kuşağı tüketicilerinin gıda seçiminde etkilendiği faktörler ve hangi kuşağın hangi faktörlere daha fazla önem verdikleri araştırılmıştır. Araştırma bulgularına göre gıdaların lezzeti, ekonomikliği ve sağlıklı olması her iki kuşak içinde önemli faktörler olarak değerlendirilmiştir. Ancak sağlık açısından, $\mathrm{X}$ kuşağının $\mathrm{Z}$ kuşağına göre daha duyarlı olduğu sonucuna varılmıştır.

Farhat vd. (2019) Pakistan'da yaşayan Y kuşağının faizsiz sigortacılık seçme niyetlerini incelemişlerdir. Elde edilen bulgular sonucunda tutum, öznel norm ve helal sertifikasyonun davranışsal niyet ile pozitif anlamlı ilişkiye sahip olduğu ve öznel normun davranışsal niyeti etkileyen en etkili faktör olduğu saptanmıştır.

Marmaya vd. (2019)'nin yapmış olduğu araştırma Malezya'da bulunan Y kuşağı tüketicilerinin helal gida satın alma niyetlerini etkileyen faktörlerin incelenmesine yönelik bir araştırmadır. Elde edilen bulgular 1şığında öznel norm ile algılanan davranış kontrolünün helal gıda satın alma niyeti üzerinde pozitif bir etkiye sahip olduğu saptanmıştır. Çalışmada tüketicilerin tutumlarının helal gida satın alımlarında önemli bir rol oynamadığı saptanmıştır.

Setiawati vd. (2019)'nin çalışmasında dindarlığın, helal farkındalığın ve helal gidaya olan tutumlara ve helal gida satın alma niyeti üzerindeki etkileri ile tutumun satın alma niyeti üzerindeki etkisi incelenmiştir. Çalışma sonucunda dindarlığın helal gidaya olan tutum üzerinde etkisi olmadığı ancak helal gida satın alma niyeti üzerinde pozitif bir etkiye sahip olduğu görülmüştür. Helal farkındalık helal gıdaya olan tutum üzerinde pozitif, helal gıda satın alma niyetinde ise önemli derecede pozitif bir etkiye sahiptir.

Ali vd. (2020) Alman ve Çinli Müslümanlar üzerinde yapmış oldukları çalışmada tüketicilerin helal et tüketimine karşı olumlu bir kişisel tutumlarının, başkalarına uyma motivasyonlarının, algılanan davranışsal kontrollerinin ve helal etin bulunabilirliğinin helal et satın alma niyetini etkilediğini tespit etmişlerdir. Çalışmada Çinli Müslüman tüketiciler helal et tüketiminde sosyal çevrelerinden daha çok etkilenmektedir. Alman tüketiciler ise algılanan davranışsal kontrol bakımından Çinli tüketicilerden daha duyarlıdırlar.

Sudarsono ve Nugrohowati (2020) çalışmalarında dindarlığın, helal ürünlere yönelik bilginin ve helal ürünlere karşı tutumun helal gıda, 
kozmetik ve eczacılık ürünlerini satın almaya yönelik niyetleri üzerindeki etkisi incelenmiştir. Çalışmada dindarlık ve tutum faktöründe tüketicilerin helal gıdaya yönelik satın alma niyetleri kozmetik ve eczacıllk ürünlerine göre daha fazla olduğu tespit edilmiştir.

Bu çalışmanın amacl; Samsun ve Almanya'nın Köln şehrinde yaşayan $X, Y$ ve $Z$ kuşağındaki tüketicilerin helal gida ürünleri konusunda sergilemiş oldukları satın alma niyetlerini ölçmektir. Farklı kuşaktaki tüketicilerin algılanan davranış kontrolleri, öznel normları, helal gıda ürünlerine karşı tutumları, helal farkındalıkları ve dini inanış biçimlerinin helal gıda ürünlerini satın alma niyeti üzerindeki etkisi incelenmek amaçlanmıştır.

Pew Araştırma Merkezi rakamlarına göre, 2010 yılında Almanya'da 4,8 milyon Müslüman (ülke nüfusunun $\% 5,8$ 'i) yaşamaktadır. Bu rakamlar, Almanya'nın Avrupa Birliği üyesi ülkeler arasında en büyük Müslüman nüfusa sahip olduğunu doğrulamaktadır. Almanya'daki Müslümanlar arasında en fazla nüfusa sahip olan topluluk Türklerdir (Sherwani vd., 2018, s.960). Bu çalışmada; Almanya'da yaşayan Müslümanlar arasında en fazla nüfusa sahip olan topluluğun Türklerin olması nedeniyle söz konusu ülkede yaşayan Türkler araştırma örneklemi olarak seçilmiştir.

\section{Yöntem}

Araştırmada, Samsun ve Almanya'nın Köln şehrinde yaşayan Türk tüketicilerin $X, Y$ ve $Z$ kuşaklarının helal sertifikalı gıda ürünlerini satın alma niyetlerini incelemek amaciyla anketler yüz yüze ve gönüllülük esasına dayalı olarak uygulanmıştır. Örneklem genişliğinin belirlenmesi için power analizi uygulanmıştır. Samsun için minimum örneklem değeri 301, Köln için ise 286 olarak tespit edilmiştir. Çalışmamızda testin gücünü artırmak amacıyla Samsun için 411, Köln için 406 kişiye yüz yüze anket yöntemi gerçekleştirilmiştir (Keskin, 2012, s.116). Araştırmada kullanılacak anket formu için 29.05.2020 tarihinde Samsun Üniversitesi Etik Kurulu onayı alınmıştır. Araştırmada helal ürün grubu olarak sadece gida ürünleri baz alınmıştır. Katılımcıların $X, Y$ ve $Z$ kuşakları içerisinde yer alması gerektiğinden 55 yaş ve üzerindekiler 
çalışmaya dahil edilmemiştir. Anket 5'li Likert tipi ölçekle (1-kesinlikle katılmıyorum ile 5- kesinlikle katılıyorum) hazırlanarak değişkenler toplam 37 ifadeden oluşmaktadır. Ayrıca ankette tüketicilerin demografik verilerine dair ifadeler yer almaktadır. Çalışmada hipotezler oluşturulurken teorik altyapıları incelenmiş ve hipotezlerin geçmiş çalışmalarda hangi sonuçlara varıldığı ortaya konulmuştur.

Dindarlık: Dindarlık, bireyin benimsediği dini kabullenmesi ve kabullendiği bu dinin kurallarına uyarak yaşaması anlamına gelmektedir. Dindarlık anlayışı, farklı dine mensup kişiler arasında değiştiği gibi aynı dine mensup kişiler arasında da farklılık görülmektedir (Yener, 2011, s.91).

Zakaria vd. (2017)'nin çalışması dindarlığın helal satın alma niyeti üzerindeki en etkili faktör olduğunu göstermiştir. Bununla birlikte Alam ve Sayuti (2011) çalışmasında dindarlığın satın alma niyetini düşük bir oranda etkilediği sonucuna ulaşmıştır. Sherwani vd. (2018b) Almanya'daki Türk Müslümanların helal et tüketimi üzerine yapmış olduğu çalışmasında dindarlık düzeyleri yüksek olan tüketicilerin helal et satın alma niyetlerinin yüksek olduklarını belirtmiştir. Sevim vd. (2016) çalışmasında Almanya'daki Türk göçmenlerin tüketim kararlarında dinin ve kültürün etkisi olduğunu tespit etmiştir. Literatürde yapılan bu çalışmalar dindarlığın helal sertifikalı ürünlerin satın alma niyetini olumlu yönde etkilediğini göstermektedir.

Hı: Dindarlık, helal sertifikalı gıda ürünleri satın alma niyetini pozitif yönde etkiler.

H1a: Dindarlık, Samsun'da yaşayan tüketicilerin helal sertifikalı gıda ürünleri satın alma niyetini pozitif yönde etkiler.

Hib: Dindarlık, Köln'de yaşayan tüketicilerin helal sertifikalı gıda ürünleri satın alma niyetini pozitif yönde etkiler.

Algılanan Davranış Kontrolü: Bireylerin belirli bir davranışı gerçekleştirme yeteneklerine ilişkin algılarını ifade etmektedir. Diğer bir ifadeyle belirli bir durumda kişilerin gerçek performansının ne kadar kolay veya ne kadar zor olduğu anlamına gelmektedir (Khan ve Azam, 2016, s.23). Omar vd. (2012) yaptıkları çalışmada, bir bireyin helal gida satın alma konusunda algılanan davranışsal kontrolleri ne kadar 
yüksekse, o bireyin helal gıda satın alma niyetlerinin o kadar yüksek olduğunu ortaya koymuşlardır.

$\mathbf{H}_{2}$ : Algılanan davranış kontrolü, helal sertifikalı gıda ürünleri satın alma niyetini pozitif yönde etkiler.

$\mathbf{H}_{2 a}$ : Algılanan davranış kontrolü, Samsun'da yaşayan tüketicilerin helal sertifikalı gıda ürünleri satın alma niyetini pozitif yönde etkiler.

$\mathbf{H}_{2 \mathbf{b}}$ : Algılanan davranış kontrolü, Köln'de yaşayan tüketicilerin helal sertifikalı gıda ürünleri satın alma niyetini pozitif yönde etkiler.

Davranışa Yönelik Tutum: Tutumlar, bireylerin bir kişiye, nesneye, fenomene veya bir ürüne karşı olumlu veya olumsuz tepkilerini ifade etmektedir. Tutumlar, tüketicilerin belirli bir ürün kategorisine nasıl yaklaştığını veya üründen kaçınıp kaçınmadığını yansıtabildiğinden, helal gıda bağlamında ürüne yönelik olumlu tutum helal gida tüketimini etkilemesi beklenmektedir (Akın ve Okumuş, 2020, s.3). Tuhin vd. (2020) yapmış oldukları çalışmada davranışa yönelik tutumun satın alma niyeti üzerinde pozitif bir etkiye sahip olduğunu göstermişlerdir. Pradana vd. (2020b) çalışmasında helal gıdaya yönelik tutumun helal satın alma niyeti üzerinde pozitif ve yüksek bir etkiye sahip olduğunu göstermiştir.

H3: Helal ürünlere yönelik tutum, helal sertifikalı gıda ürünleri satın alma niyetini pozitif yönde etkiler.

$\mathbf{H}_{\text {3a: }}$ Helal ürünlere yönelik tutum, Samsun'da yaşayan tüketicilerin helal sertifikalı gıda ürünleri satın alma niyetini pozitif yönde etkiler.

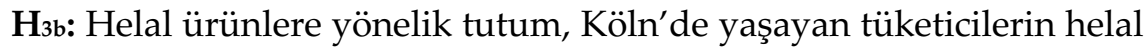
sertifikalı gıda ürünleri satın alma niyetini pozitif yönde etkiler.

Öznel Norm: Planlı davranış teorisinin bir başka değişkeni de öznel normdur. Fishbein ve Ajzen'e (1977) göre, bireyin, potansiyel referans grubun veya bireylerin verilen davranışı gerçekleştirmeyi onaylama veya onaylamama olasılığına ilişkin algısı olarak tanımlanmaktadır. Abu-Hussin vd. (2017) Singapur'da yaşayan Müslüman azınlığın helal gıda satın alma niyetlerini incelediği çalışmada öznel normların helal gida satın alma niyetlerini pozitif yönde etkilediğini tespit etmiştir.

$\mathbf{H}_{4}$ : Öznel norm, helal sertifikalı gida ürünleri satın alma niyetini pozitif yönde etkiler. 


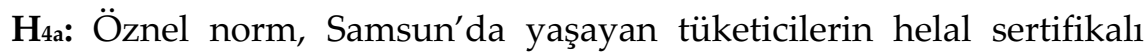
gıda ürünleri satın alma niyetini pozitif yönde etkiler.

$\mathbf{H}_{4 b}$ : Öznel norm, Köln'de yaşayan tüketicilerin helal sertifikalı gıda ürünleri satın alma niyetini pozitif yönde etkiler.

Helal Farkındalık: Farkındalık, olayları ve nesneleri hissetme, algılama ve bunlarla ilgili bilgiye sahip olma yeteneğidir (Aziz ve Chok, 2013, s.7). Helal farkındalığı, bir Müslümanın dini kuralları gereği helal ve haram konusunda sahip olduğu bilgi düzeyidir. Aziz ve Chok (2013) çalışmasında helal farkındalığın satın alma niyeti üzerinde etkili olduğunu göstermiştir. Zakaria vd. (2017) yapmış olduğu çalışmada bu etkiyi destekler niteliktedir. Bu durumdan hareketle çalışmamızda helal farkındalığın helal satın alma niyeti üzerinde anlamlı bir etkiye sahip olduğu beklenmektedir.

H5: Helal farkındalık, helal sertifikalı gıda ürünleri satın alma niyetini pozitif yönde etkiler.

H5a: Helal farkındalık, Samsun'da yaşayan tüketicilerin helal sertifikalı gıda ürünleri satın alma niyetini pozitif yönde etkiler.

H5b: Helal farkındalık, Köln'de yaşayan tüketicilerin helal sertifikalı gıda ürünleri satın alma niyetini pozitif yönde etkiler.

Helal Gıda Satın Alma Niyeti: Herhangi bir ürüne yönelik satın alma niyeti, o ürünün satın alınmasına yönelik planlama yapılması anlamına gelmektedir. Satın alma niyeti, tüketicinin bir ürünü satın almak için hazır olup olmadığını ve satın alma olasılı̆̆ını göstermektedir ( Başaran Alagöz ve Demirel, 2017, s.460). Yapılan literatür taramalarında helal gıdalara yönelik satın alma niyetlerini etkileyen birçok faktörün olduğu tespit edilmiştir. Yapılan bu çalışmada Planlı Davranış Teorisi baz alınarak yukarıda belirtmiş olduğumuz faktörlerin helal gıdalara yönelik yönelik satın alma niyeti üzerindeki etkisi incelenmiştir.

Tüketicilerin dindarlık, algılanan davranış kontrolü, satın alma niyeti, helal gıdaya yönelik tutum ve öznel normlar değişkeni Khan ve Azam (2016)'ın yapmış oldukları çalışmada kullanmış oldukları ölçeğin Türkçeye çevrilmesi ve araştırmaya uyarlanmasıyla, helal farkındalık değişkeninin ise Awan vd. (2015)'nin yapmış olduğu çalışmada kullandıkları değişkenin Türkçeye çevrilmesi ve araştırmaya 
uyarlanmasıyla hazırlanmıştır. Araştırma modelini Ajzen (1991) tarafından oluşturulan Planlı Davranış Teorisi'nin Khan ve Azam (2016)'ın çalışmasından dindarlık faktörü ve Awan vd. (2015)'ın çalışmasından helal farkındalık faktörü eklenerek geliştirilmiş olan kavramsal model oluşturmaktadır.

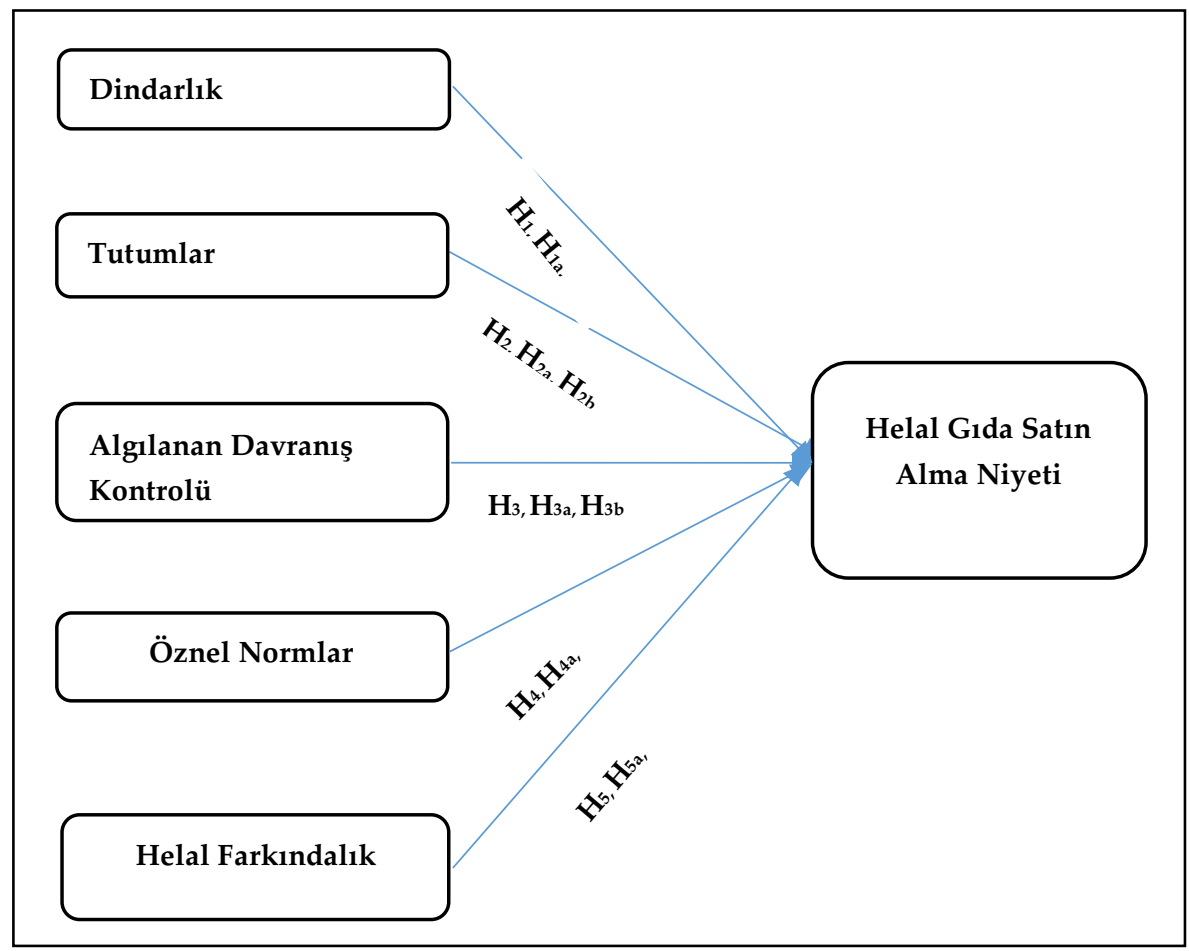

Şekil 1. Araştırma Modeli

\section{Bulgular}

Araştırmada elde edilen verilerin analizi IBM SPSS 25 ve R v3.6.2 paket programları kullanılarak gerçekleştirilmiştir. Uygulanan analizlerin ilk safhasında, demografik bulgulara yer verilmiştir. İkinci aşamada ise, araştırma modelinde yer alan bağımsız değişkenlerin bağımlı değişkeni etkileme düzeylerinin değerlendirilmesi Yapısal Eşitlik Modeli (YEM) Analizi kullanılarak değerlendirilmiştir. 
IBM SPSS AMOS ve Smart PLS gibi yazılımlar yüksek kullanım maliyetleri lisans gerektirmektedir. Bunlarla birlikte R programı internet ortamında kolay ulaşılabilen bir programdir. $\mathrm{Bu}$ program araştırmacıların istatistiki işlemlerini kolay bir şekilde yapabilecekleri ve internet üzerinden her an ulaşabilecekleri ve bununla birlikte Dünya üzerindeki istatistikçilerin sürekli güncellediği bir programdır (Er ve Sönmez, 2005, s.72).

Uygulanan analizlerin ilk safhasında, kullanılan ölçeklerin güvenirlik analizi gerçekleştirilmiştir. Ölçeğin güvenirliği bir iç tutarlılık katsayı tekniği olan Cronbach's Alpha tekniği kullanılarak değerlendirilmiştir. İkinci aşamada ise, araştırma modelinde yer alan bağımsız değişkenlerin bağımlı değişkeni etkileme düzeylerinin değerlendirilmesi Yapısal Eşitlik Modeli (YEM) Analizi kullanılarak değerlendirilmiştir (Fox vd., 2020).

\section{Demografik Bulgular}

Araştırmaya katılan Samsun ve Köln'de yaşayan tüketicilerin demografik verilerine dair bilgiler Tablo 1'de gösterilmektedir.

Araştırmaya katılan Samsun'da yaşayan tüketicilerin demografik verilerinin özet istatistikleri incelendiğinde \%30,2'sinin (124 kişi) Z (1-19 yaş) kuşağı, \%40,1'inin (165 kişi) Y (20-39 yaş) kuşağı, \%29,7'sinin (122 kişi) X (40-54 yaş) kuşağı olduğu, \%28,5'inin (117 kişi) 999 TL ve altı gelir düzeyine, \%22,9'unun (94 kişi) 2000-2999 TL arası gelir düzeyine sahip olduğu, \%47,4'ünün (195 kişi) lise eğitim seviyesine, \%21,2'sinin (87 kişi) lisans eğitim seviyesine sahip olduğu, \%35,3'ünün (145 kişi) öğrenci, \%29,7'sinin (122 kişi) işçi olduğu saptanmıştır (Tablo 1).

Araştırmaya katılan Köln'de yaşayan Türk tüketicilerin demografik verilerinin özet istatistikleri incelendiğinde, \%48'inin (195 kişi) Y (20-39 yaş) kuşağ 1 ve \%35,5'inin (144 kişi) X (40-54 yaş) kuşağı, \%16,5'inin (67 kişi) Z (1-19 yaş) kuşağı olduğu, \%31,8'inin (129 kişi) 899 euro ve altı gelir düzeyine, \%24,6'sının (100 kişi) 1800-2699 euro arası gelir düzeyine sahip olduğu, , \%45,6'sının (185 kişi) Almanya lise eğitim seviyesine, \%24,4'ünün (99 kişi) lisans eğitim seviyesine sahip olduğu, \%38,9'unun (158 kişi) işçi, \%28,7' sinin (117 kişi) öğrenci olduğu, \%46,1'inin (187 kişi) 
T.C. vatandaşı olduğu, \%55,9'unun (227 kişi) doğum yerinin Almanya olduğu tespit edilmiştir (Tablo 1).

Tablo 1. Samsun ve Köln'deki tüketicilerin demografik verilerinin özet istatistikleri

\begin{tabular}{|c|c|c|c|c|c|}
\hline Samsun & & & Köln & & \\
\hline Cinsiyet & $\mathbf{N}$ & $\%$ & Cinsiyet & $\mathbf{N}$ & $\%$ \\
\hline Kadın & 189 & 46,0 & Kadın & 200 & 49,3 \\
\hline Erkek & 222 & 54,0 & Erkek & 206 & 50,7 \\
\hline Medeni Durum & & & Medeni Durum & & \\
\hline Evli & 195 & 47,4 & Evli & 250 & 61,6 \\
\hline Bekar & 216 & 52,6 & Bekar & 156 & 38,4 \\
\hline Kuşak & & & Kuşak & & \\
\hline $\mathrm{Z}$ (1-19 yaş) & 124 & 30,2 & $\mathrm{Z}$ (1-19 yaş) & 67 & 16,5 \\
\hline Y (20-39 yaş) & 165 & 40,1 & Y (20-39 yaş) & 195 & 48,0 \\
\hline$X(40-54$ yaş $)$ & 122 & 29,7 & X (40-54 yaş) & 144 & 35,5 \\
\hline Gelir Düzeyi & & & Gelir Düzeyi & & \\
\hline 999 TL ve altı & 117 & 28,5 & $899 €$ ve altı & 129 & 31,9 \\
\hline 1000-1999 TL & 36 & 8,8 & $900-1799 €$ & 68 & 16,7 \\
\hline 2000-2999 TL & 94 & 22,9 & $1800-2699 €$ & 100 & 24,6 \\
\hline 3000-3999 TL & 66 & 16,0 & $2700-3599 €$ & 59 & 14,5 \\
\hline 4000-4999 TL & 53 & 12,9 & $3600-4499 €$ & 30 & 7,4 \\
\hline 5000 TL ve üstü & 45 & 10,9 & $4500 €$ ve üzeri & 20 & 4,9 \\
\hline Eğitim Seviyesi & & & Eğitim Seviyesi & & \\
\hline İlköğretim & 58 & 14,1 & İlköğretim Türkiye & 14 & 3,4 \\
\hline Lise & 195 & 47,4 & İlköğretim Almanya & 4 & 1,0 \\
\hline Yüksekokul & 30 & 7,3 & Lise Almanya & 185 & 45,6 \\
\hline Lisans & 87 & 21,2 & Lise Türkiye & 55 & 13,5 \\
\hline \multirow[t]{3}{*}{ Lisansüstü } & 41 & 10,0 & Yüksekokul & 30 & 7,4 \\
\hline & & & Lisans & 99 & 24,4 \\
\hline & & & Lisansüstü & 19 & 4,7 \\
\hline Meslek & & & Meslek & & \\
\hline Çalışmıyor & 23 & 5,6 & Çalışmıyor & 21 & 5,2 \\
\hline Öğrenci & 45 & 35,3 & Öğrenci & 117 & 28,8 \\
\hline Ev Hanımı & 35 & 8,5 & Ev Hanımı & 77 & 19,0 \\
\hline Emekli & 9 & 2,2 & Emekli & 4 & 1,0 \\
\hline Memur & 54 & 13,1 & Memur & 8 & 2,0 \\
\hline İşçi & 122 & 29,7 & İşçi & 158 & 38,9 \\
\hline \multirow[t]{11}{*}{ İşveren } & 23 & 5,6 & İşveren & 21 & 5,1 \\
\hline & & & Vatandaşlık & & \\
\hline & & & TC & 187 & 46,1 \\
\hline & & & Alman & 164 & 40,4 \\
\hline & & & Çifte Vatandaş & 55 & 13,5 \\
\hline & & & Doğum Yeri & & \\
\hline & & & Türkiye & 179 & 44,1 \\
\hline & & & Almanya & 227 & 55,9 \\
\hline & & & Kültür Tarzı & & \\
\hline & & & Türk & 381 & 93,8 \\
\hline & & & Alman & 25 & 6,2 \\
\hline
\end{tabular}




\section{Hipotezlerin Test Edilmesi}

Araştırmaya katılan Samsun ve Köln'deki tüketicilerin ölçeklere verdikleri yanıtlara göre yapısal eşitlik modellemesi sonuçları Şekil 2 ve Şekil 3'de verilmiştir.

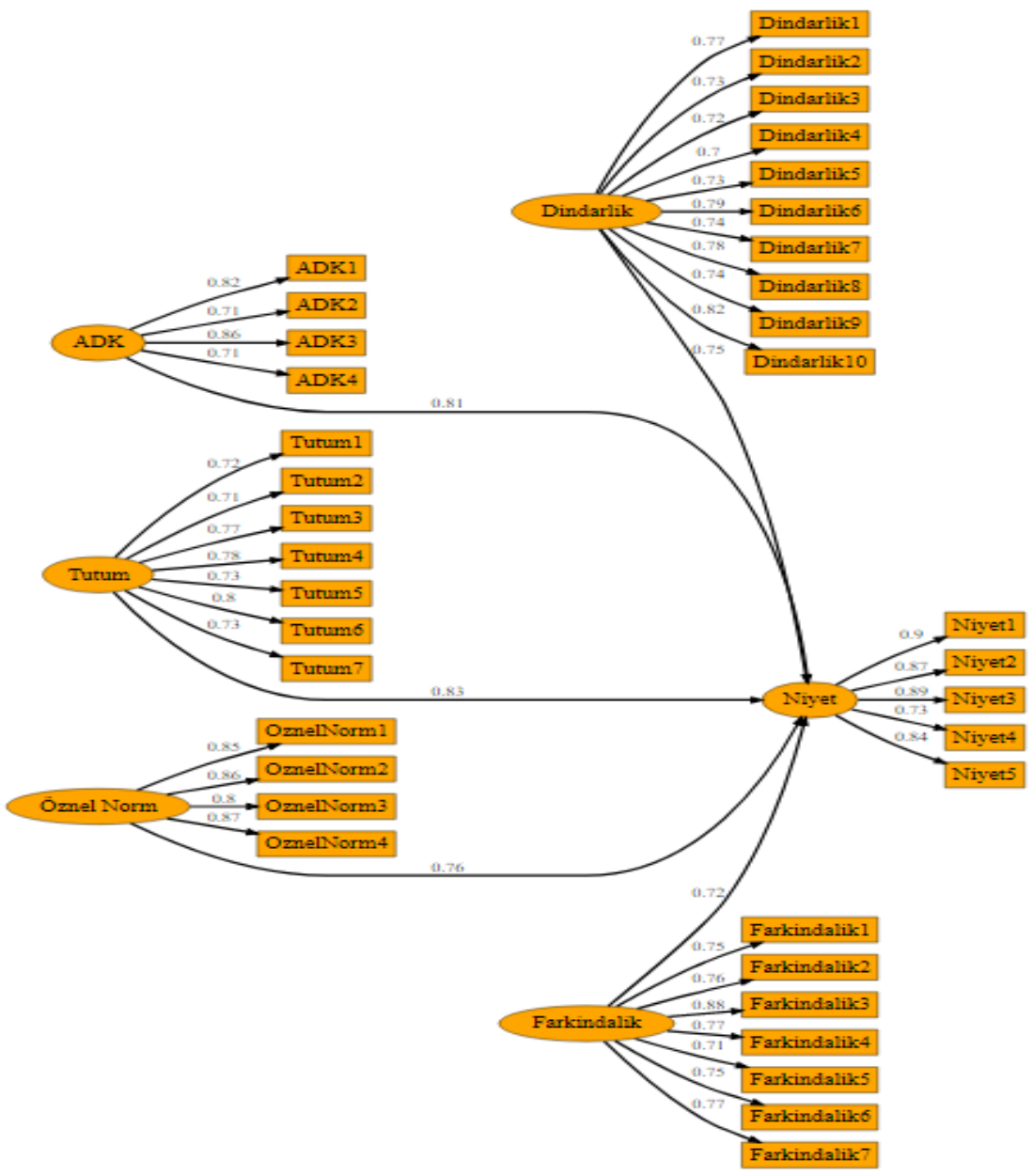

Şekil 2. Samsun'daki tüketicilerin ölçeklere verdikleri yanıtlara göre yapısal eşitlik modellemesi 


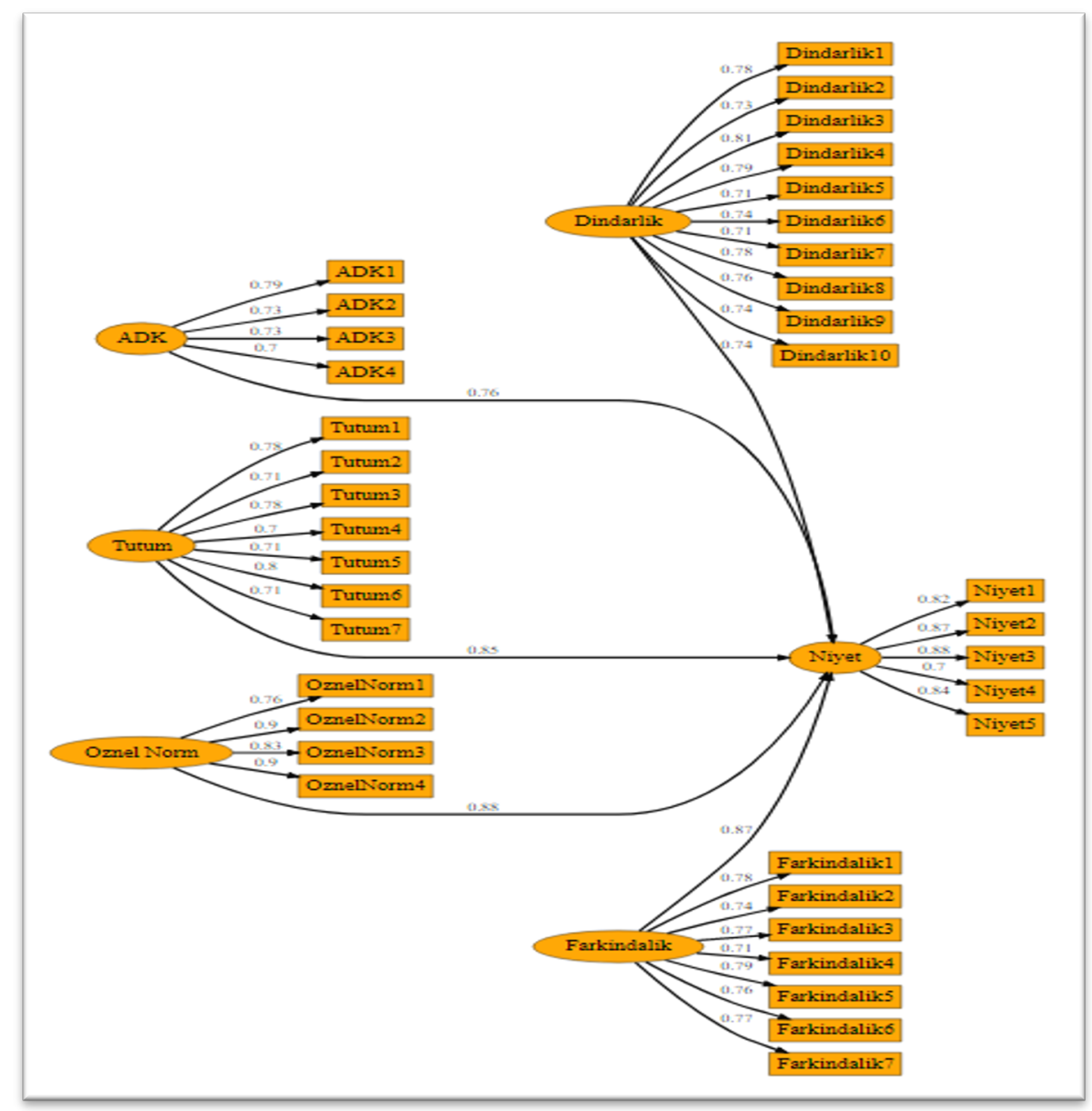

Şekil 3. Köln'deki tüketicilerin ölçeklere verdikleri yanttlara göre yapısal eşitlik modellemesi

Araştırmaya katılan Samsun ve Köln'deki tüketicilerin ölçeklere verdikleri yanıtlara göre yapısal eşitlik modelleme sonuçları incelendiğinde hem Samsun ve hem de Köln'deki tüketicilerin yanıtlarına göre tüm eşik değerlerin iyi uyum gösterdiği saptanmıştır (Tablo 2). 
Tablo 2. Samsun ve Köln'deki tüketicilerin ölçeklere verdikleri yanıtlara göre yapısal eşitlik modellemesi sonuçları

\begin{tabular}{|c|c|c|c|c|c|}
\hline $\begin{array}{l}\text { Uyum } \\
\text { indeksi }\end{array}$ & Eşik Değerler & $\begin{array}{l}\text { Samsun YEM } \\
\text { Sonuçları }\end{array}$ & Uyum & $\begin{array}{l}\text { Köln YEM } \\
\text { Sonuçları }\end{array}$ & Uyum \\
\hline Ki-Kare/sd & $0 \leq \mathrm{Ki}-\mathrm{kare} / \mathrm{sd} \leq 2$ & 0,917 & İyi uyum & 1,072 & İyi uyum \\
\hline p değeri & $0,10 \leq \mathbf{p} \leq 1,00$ & 0,928 & İyi uyum & 0,104 & İyi uyum \\
\hline RMSEA & $0 \leq \mathbf{R M S A} \leq 0,05$ & 0,005 & İyi uyum & 0,013 & İyi uyum \\
\hline NFI & $0,90 \leq \mathbf{N F I} \leq 1,00$ & 0,983 & İyi uyum & 0,966 & İyi uyum \\
\hline CFI & $0,97 \leq \mathrm{CFI} \leq 1,00$ & 1,000 & İyi uyum & 0,997 & İyi uyum \\
\hline SRMR & $\mathbf{S R M R}<0,08$ & 0,052 & İyi uyum & 0,067 & İyi uyum \\
\hline GFI & $0,95 \leq \mathrm{GFI} \leq 1,00$ & 0,986 & İyi uyum & 0,972 & İyi uyum \\
\hline AGFI & $0,90 \leq \mathrm{AGFI} \leq 1,00$ & 0,984 & İyi uyum & 0,968 & İyi uyum \\
\hline
\end{tabular}

Samsun'daki tüketicilere uygulanan araştırma ölçeklerinin standardize faktör yükleri (SFL), açıklanan varyans ortalamaları (AVE), birleşik güvenilirlikleri (CR) ve ölçeklerin güvenilirlikleri (Cronbach's Alpha) incelendiğinde, tüm ölçeklerin $C R$ değerlerinin AVE değerlerinden büyük olduğu (CR> AVE), tüm $C R$ değerlerinin $0,7^{\prime}$ den büyük olduğu, tüm AVE değerlerinin 0,5 'den büyük olduğu ve tüm Cronbach's Alpha değerlerinin 0,7'den büyük olduğu ve tüm ölçeklerin güvenilir olduğu saptanmıştır. Köln'deki Türk tüketicilere uygulanan araştırma ölçeklerinin standardize faktör yükleri (SFL), açıklanan varyans ortalamaları (AVE), birleşik güvenilirlikleri (CR) ve ölçeklerin güvenilirlikleri (Cronbach's Alpha) incelendiğinde, tüm ölçeklerin CR değerlerinin AVE değerlerinden büyük olduğu (CR > AVE), tüm $C R$ değerlerinin $0,7^{\prime}$ den büyük olduğu, tüm AVE değerlerinin $0,5^{\prime}$ den büyük olduğu ve tüm Cronbach's Alpha değerlerinin 0,7'den büyük olduğu ve tüm ölçeklerin güvenilir olduğu saptanmıştır (Tablo 3).

Modele baktığımızda Samsun'daki tüketicilerin dindarlıklarının helal gıda satın alma niyetleri üzerinde 0,75 oranında yüksek ve pozitif yönde bir etkiye sahip olduğu, Köln'deki tüketicilerin ise 0,74 oranında yüksek ve pozitif yönlü bir etkiye sahip olduğu görülmektedir. Bu değişkenlerin p değeri 0.05 ten küçüktür. Bu duruma göre $\mathrm{H}_{1}, \mathrm{H}_{1 a}$ ve $\mathrm{H}_{1 b}$ hipotezleri kabul edilmiştir.

Tüketicilerin algilanan davranışsal kontrollerine baktığımızda $\mathrm{p}<0.05$ olmakla birlikte Samsun'daki tüketiciler 0.81 oranına, Köln'deki tüketiciler ise 0.76 oranına sahiptir. Böylelikle $\mathrm{H}_{2}, \mathrm{H}_{2 a}$ ve $\mathrm{H}_{2 b}$ hipotezleri kabul edilmiştir. 
Tablo 3. Samsun ve Köln'deki tüketicilerin ölçeklere verdikleri yanıtlara göre ölçeklerin maddelerinin SFL, CR, AVE ve a değerleri

\begin{tabular}{|c|c|c|c|c|c|c|c|c|}
\hline \multirow{2}{*}{ Ölçekler-Maddeler } & \multicolumn{4}{|c|}{ SAMSUN } & \multicolumn{4}{|c|}{ KÖLN } \\
\hline & SFL & CR & AVE & $\alpha$ & SFL & CR & AVE & $\alpha$ \\
\hline \multicolumn{9}{|l|}{ Dindarlık } \\
\hline $\begin{array}{l}\text { Dindarlık1- } \\
\text { Dindarlık10 }\end{array}$ & $\begin{array}{l}0,70- \\
0,82^{*}\end{array}$ & 0,968 & 0,566 & 0,904 & $\begin{array}{l}0,71- \\
0,81^{*}\end{array}$ & 0,968 & 0,571 & 0,897 \\
\hline \multicolumn{9}{|c|}{ Algılanan Davranış Kontrolü } \\
\hline ADK1- ADK4 & $\begin{array}{l}0,71- \\
0,86^{*}\end{array}$ & 0,933 & 0,605 & 0,737 & $\begin{array}{l}0,70- \\
0,79^{*}\end{array}$ & 0,918 & 0,544 & 0,707 \\
\hline \multicolumn{9}{|l|}{ Tutum } \\
\hline Tutum1-Tutum7 & $\begin{array}{l}0,71- \\
0,80^{*}\end{array}$ & 0,954 & 0,561 & 0,884 & $\begin{array}{l}0,71- \\
0,80^{*}\end{array}$ & 0,952 & 0,551 & 0,858 \\
\hline \multicolumn{9}{|l|}{ Farkındalık } \\
\hline $\begin{array}{l}\text { Farkındalık1- } \\
\text { Farkındalık7 }\end{array}$ & $\begin{array}{l}0,71- \\
0,88^{*}\end{array}$ & 0,959 & 0,595 & 0,814 & $\begin{array}{l}0,71- \\
0,79^{*}\end{array}$ & 0,956 & 0,578 & 0,751 \\
\hline \multicolumn{9}{|l|}{ Öznel Norm } \\
\hline ON1-ON4 & $\begin{array}{l}0,80- \\
0,87^{*}\end{array}$ & 0,956 & 0,714 & 0,908 & $\begin{array}{l}0,76- \\
0,90^{*}\end{array}$ & 0,958 & 0,721 & 0,909 \\
\hline \multicolumn{9}{|l|}{ Niyet } \\
\hline Niyet1-Niyet5 & $\begin{array}{l}0,73- \\
0,90^{*}\end{array}$ & 0,965 & 0,719 & 0,922 & $\begin{array}{l}0,70- \\
0,88^{*}\end{array}$ & 0,959 & 0,679 & 0,897 \\
\hline
\end{tabular}

Helal gıdaya yönelik tutum değişkenine bakıldığında $p$ değerinin 0.05 'den küçük olduğu görülmektedir. Samsun'daki tüketicilerin tutumları satın alma niyetini 0,83 düzeyinde pozitif yönde etkilerken, Köln'deki tüketicilerin tutumları satın alma niyetini 0,85 oranında pozitif yönlü bir şekilde etkilemektedir. Çıkan bu sonuçlara göre $\mathrm{H}_{3}, \mathrm{H}_{3 a}$ ve $\mathrm{H}_{3 b}$ hipotezleri kabul edilmiştir.

Öznel norm değişkenine baktığımızda Samsun'daki tüketicilerin öznel normlarının 0,76 oranında helal satın alma niyetine etki ettiğini, Köln'deki tüketicilerin vermiş olduğu cevaplarda ise öznel normların niyeti 0,88 oranında etkilediği görülmektedir. Anlamlılık düzeyi olarak $\mathrm{p}$ değeri 0.05 'den küçük olduğu için öznel normlar satın alma niyetini pozitif ve anlamlı bir şekilde etkilemektedir. $\mathrm{H}_{4}, \mathrm{H}_{4 a}$ ve $\mathrm{H}_{4 b}$ hipotezleri kabul edilmiştir.

Modelde tüketicilerin helal farkındalıklarının helal satın alma niyeti üzerindeki etkisi incelenmiştir. Sonuçlara göre $\mathrm{p}<0.05$ olup Samsun'daki tüketiciler 0.72 oranındadır. Köln'deki tüketiciler ise 0.87 'lik bir orana 
sahiptir. Bu değerlere baktığımızda Helal farkındalığın helal satın alma niyeti üzerinde pozitif yönlü ve anlamlı bir etkiye sahip olduğu görülmektedir. $\mathrm{H}_{5}$, $\mathrm{H}_{5 a}$ ve $\mathrm{H}_{5 b}$ hipotezleri kabul edilmiştir.

\section{Tartışma ve Sonuç}

Modelde Samsun'daki tüketicilerin dindarlıklarının helal gıda satın alma niyetleri üzerinde yüksek ve pozitif yönde bir etkiye sahip olduğu, Köln'deki tüketicilerin de yüksek ve pozitif yönlü bir etkiye sahip olduğu görülmektedir.

Çalışmadan elde edilen sonuçlara göre tüketicilerin dindarlıkları onların helal sertifikalı ürünleri satın alma niyetlerini etkilemektedir. Din ile ilgili meselelere önem veren, dini anlama konusunda kendini geliştiren ve dininin bütün yaşayış tarzını etkilediğini belirten tüketicilerin çok bilinen bir marka olmasa bile helal ürünleri satın alma niyetine sahip oldukları görülmektedir. Ayrıca dinine bağlı kişilerin helal ürünleri çok bilindik bir marka olmasa bile satın alma niyetinde oldukları saptanmıştır. Alam ve Sayuti (2011) yapmış olduğu çalışmasında dindarlık faktörünün satın alma niyetine az da olsa etki ettiğini doğrulamıştır. Setiawati vd. (2019) yapmış olduğu çalışmasında dindarlık satın alma niyeti üzerinde olumlu ve anlamlı bir etkiye sahiptir. Zakaria vd. (2017) Malezya'da yapmış olduğu çalışmada dindarlık faktörünün satın alma niyeti üzerindeki en etkili faktör olduğu sonucuna ulaşmıştır.

Çalışmanın bir başka değişkeni olan ve kişinin davranışı gerçekleştirme motivasyonu olan algılanan davranış kontrol değişkeni helal gıda satın alma niyetleri üzerinde pozitif ve anlamlı bir etkiye sahiptir. Çalışmada tüketiciler, helal ürün satın alma konusunda bilgi sahibi olduklarını ve mağaza, market vb. yerlerde helal ürünlerin bulunması durumunda diğer ürünlere göre pahalı olsalar bile helal ürünleri satın alma niyetleri olduklarını ve hatta bunun için fazladan yolculuk yapabileceklerini belirtmişlerdir. Göktürk (2019) yılında yayımladığ1 yüksek lisans tezinde aynı sonuca ulaşmıştır. Bununla birlikte Khan vd. (2016), Alam ve Sayuti (2011) ve Khalek ve Ismail (2015) çalışmalarında bu etkiyi desteklemektedirler. 
Tutum değişkenine bakıldığında hem Samsun hem de Köln'de yaşayan tüketicilerin satın alma niyetleri üzerinde pozitif yönlü bir şekilde etkisi bulunmaktadır. Tüketicilerin helal gıdaya yönelik tutumları ne kadar yüksek ise satın alma niyetleri de aynı yönde yüksektir. Tüketiciler helal onay belgesinin helal satın alma niyetleri üzerinde etkili olduğunu düşünmektedir. Bununla birlikte helal sertifikalı ürünlerin daha kaliteli olduğunu bu nedenle çok bilinen bir marka olmasa bile herkesin helal ürünleri tercih etmesi gerektiğini belirtmişlerdir. Tüketiciler piyasaya yeni çıkan helal ürünleri takip ederek pahalı bile olsa helal olanları satın alma niyetindedirler. Bashir (2019) çalışmasında tutumun satın alma niyetini olumlu yönde etkilediğini, tüketicilerin tutumları ne kadar yüksekse satın alma niyetlerinin de o kadar yüksek olduğunu belirtmiştir. Ayrıca Lada vd. (2009) ve Alam ve Sayuti (2011)'de çalışmalarında tutumun satın alma niyeti üzerindeki etkisini göstermiştir.

Öznel norm değişkenine baktığımızda Samsun'daki tüketicilerin öznel normlarının 0.76 oranında helal satın alma niyetine etki ettiğini, Köln'deki tüketicilerin vermiş olduğu cevaplarda ise öznel normların niyeti 0.88 oranında etkilediği görülmektedir. Tüketiciler helal sertifikalı ürünleri satın alırken çevrelerinden etkilenmektedirler. Aile bireyleri, arkadaş çevresi kişinin helal ürün tercihlerinde yüksek seviyede etkiliyse tüketicilerin de helal ürünleri satın almaya yönelik niyetleri yüksektir. Sosyal çevre ile desteklenen tüketici çok bilinen bir marka olmasa ve diğer ürünlere göre biraz pahalı olsalar bile helal ürünleri satın almaya niyetlidirler. Mukhtar ve Butt (2012) çalışmasında öznel normların satın alma niyetini önemli ölçüde etkilediğini göstermiştir. Bu çalışma yapmış olduğumuz çalışmayı destekler niteliktedir.

Çalışmanın bir başka değişkeni olan helal farkındalık değişkeni her iki şehirde yaşayan tüketicilerin helal sertifikalı gıda satın alma niyetleri üzerinde önemli bir etkiye sahiptir. Tüketicilerin helal ürünlere yönelik farkındalıkları arttıkça helal satın alma niyetleri de artmaktadır. Ürünlerin içeriğini araştırıp helal içeriğe sahip olduklarına kanaat getiren tüketiciler ürünlerin pahalılık durumlarını sonraki plana atmaktadırlar. Helal ürünlerin üretimi, sertifikalama süreci ve pazarlamasinda resmi kurumların sorumlu olduklarının ve bu kurumların denetimlerini sürdürdüğünün bilinci tüketicilerin satın alma 
niyetlerine olumlu yansımaktadır. Aziz ve Chok (2013) yapmış olduğu çalışmasında helal farkındalığın satın alma niyetini pozitif yönde etkilediğini göstermiştir. Zakaria vd. (2017) Malezya'daki tüketiciler üzerinde yaptığı çalışmanın sonucu da bu hipotezi desteklemektedir. Awan vd. (2015) helal farkındalığın satın alma niyeti üzerinde düşük ve pozitif bir etkiye sahip olduğu sonucuna ulaşmıştır.

Çalışmanın geneline bakıldığında tüketicilerin helal gida konusundaki düşünceleri olumludur. Tüketiciler helal gıdayı pahalı olsalar bile tercih etme eğilimindedirler. Bununla birlikte helal gıdaların marka bilinirliğinin olması taraftarıdırlar. Ayrıca tüketiciler için helal sertifika oldukça yüksek önem arz etmektedir. Tüketicilerin helal bilinçlerinin artırılması için işletmelerin tutundurma faaliyetlerini artırmaları gerekmektedir. Sosyal medya, televizyon reklamları, kamu spotları, dergiler, broşürler, makaleler aracılığıyla tüketiciler helal gıda konusunda bilinçlendirilebilir. Helal gida konusunda yetkili kurum ve kuruluşların sürecin içerisinde yer alması tüketicilerin helal gıdaya olan güvenlerini artırmaktadır. Bu nedenle helal sertifika veren kurum ve kuruluşların işletmeleri sıkı denetime tabi tutmaları gerekmektedir. Üniversiteler bilimsel çalışmaların kilit noktalarındandır. Bu yüzden üniversiteler helal konusunda araştırma ve geliştirme faaliyetlerini gerçekleştirmek adına helal enstitülerini kurarak sistematik bir eğitim sistemiyle helal pazarın ihtiyaç duyduğu uzmanları da üniversite bünyesinde yetiştirmiş olurlar. Sivil toplum kuruluşlarının yapmış oldukları faaliyetler tüketicilerin herhangi bir konuda olumlu ya da olumsuz fikir edinmelerini sağlamaktadır. Bu bağlamda helal konusunda sivil toplum kuruluşlarının yapacakları eğitici ve tanıtıcı faaliyetler tüketicilerin helal gıdaya yönelik algılarını artıracaktır ve algıları artan tüketiciler helal konusunda bilgi sahibi olarak helal farkındalıkları artacaktır. Böylece tüketicilerin helal farkındalıkları arttıkça helal gıdaya yönelik satın alma niyetleri de artacaktır. 
EXTENDED ABSTRACT

\title{
An Investigation of the Intentions of Generations $X$, $Y$ and $Z$ to Buy Halal Certified Foods: The Sample of Samsun-Köln
}

\author{
Mustafa Kemal Yılmaz- İsmail Can Albayrak \\ Samsun University
}

In today's world, there are billions of people from different races having various religious beliefs and languages. The concept of a generation has emerged through the analysis of these communities born in the same period of time, experiencing similar conditions, and witnessing the significant events of the relevant era. These generations have been categorized into five groups. However, this study has focused on only three of them. The generations included in this study are Gen X, Gen Y, and Gen $Z$. Gen $X$ is the generation comprising the people born between the years 1965 and 1979. Gen X represents a generation having opposing views, drawing attention with their distinctive dressing style, and interiorizing hard music culture and punk lifestyle. When this generation is examined from the perspective of consuming habits, Gen X represents a familial profile mainly composed of parents and generally spending money for his/her family in this era. Gen Y, having a great potential of consuming, consists of the people born between the years 1980 and 1999. This generation is self-centered, independent, cooperative, variable, and self-confident. As Gen $\mathrm{Y}$ has emerged in the period when technology has started to develop, this generation has grown up together with technology; therefore, they are different from their parents.

The generation born after 2000 is known as Gen Z. The most striking characteristic of this generation is their ultimate relationship with technology because the members of Gen $\mathrm{Z}$ were born in the era of technology. This generation includes the youth of today's world. Since they are still young, their expenses mostly depend on the sources provided by their parents. On the other hand, they influence the decisions of their parents in the ultimate purchasing process. Although 
the members of a generation are included in a specific group, it may not be correct to state that they exhibit the same behaviors all the time. These groups of generations have different religious beliefs, genders, and nationalities, and they differ from each other in these aspects. More specifically, the religion-based differences have significant impacts on the changes observed in the consuming behaviors of the people. Muslims may be members of different generations; however, in all circumstances, they are supposed to obey the orders and prohibitions of Allah regarding consumption. The sensitivity on the issue of "halal" consumption has enhanced due to the migration of Muslims to other countries having different religious beliefs and increasing numbers of Muslim populations all over the world. Since the concept of "halal" is the opposite of "haram" (which means "forbidden") in Islamic Law, this notion is quite significant for Muslims. The Muslim consumers have started to question especially the ingredients of foods from the perspective of "halal", and Halal Certification has been initiated in order to eliminate the concerns of the Muslim populations on the consumption of "halal" foods. Subsequent to the proliferation of the "halal" concept in the world, significant development has been observed in the markets of halal products.

The Muslims, which constitute approximately one-quarter of the world's population, have become the potential consumers of the halal markets. These markets designed for such a great population have been developing together with increasing numbers of Muslims. With this increasing population, the halal markets are expected to reach 3.7 trillion US dollars until 2019 and 10 trillion US dollars until 2030. In line with this trend, Albert Heijn and Carrefour, two of the largest retail companies, have added halal meat to their lists of products. Similarly, the world's leading fast-food brands such as McDonald's and KFC have introduced halal foods in their categories of products. All these developments illustrate that the companies update their existing product portfolios by including halal foods in accordance with the demands of the increasing Muslim population. The growth in the halal markets is at a pace that cannot be disregarded by the companies, and it provides new market opportunities for numerous corporations. 
This study has analyzed the factors influencing the halal purchasing habits of the Turkish consumers living in Samsun and Köln and selected from different groups of generations. Moreover, the generation-based differences have been examined in the selected populations of these two countries. The analysis section of the study is based on the reliability analysis, model test and Structural Equation Modelling (SEM) applied with the use of the $\mathrm{R}$ program. According to the data obtained from this study, it has been concluded that the devoutness of the consumers living in Samsun and Köln has an impact on their habits to purchase halalcertified products. It has been observed that the consumers giving importance to religious issues, developing themselves to understand the religion more effectively, and shaping their lifestyles in accordance with the rules of their religion prefer to purchase halal products even though their brands are not widely known. The variable of perceived behavioral control, which is another variable of the present study, has a significant and positive impact on purchasing halal products. In this study, the consumers have stated that they have sufficient knowledge on the issue of purchasing halal products, that they prefer to buy halal products in supermarkets, stores, etc., if any, even though the halal products are more expensive than the others, and that they can even change their locations to purchase these products. The attitudes of consumers towards halal foods have a positive impact on their purchasing behaviors.

The more conscious are the consumers in terms of halal foods, the higher are the rate of purchasing these halal products. Consumers think that the halal certificates influence their decisions on purchasing the relevant products. They have also remarked that the halal-certified products are of higher quality and that everyone should prefer halal products for this reason even though their brands are not well-known. Consumers keep up with the new halal products introduced in the markets and they prefer to purchase halal products even if they are more expensive. Consumers are influenced by their entourage while purchasing halal-certified products. If the family members or friends highly influence the decision-making process of an individual in purchasing halal products, this individual has a stronger intention to buy these products. The consumers supported by their social environments 
prefer to buy halal products even if their brands are not widely known or they are more expensive than other products. If the consumers have a higher awareness of halal products, they are more devoted to purchasing halal products. The consumers analyzing the ingredients of the products in terms of the halal concept push the expensiveness of the products into the background. The purchasing habits of the consumers are positively influenced by the fact that the official institutions are responsible for the production, certification, and marketing of halal products, and that they continuously carry out inspections on this issue. From a general perspective, this study has concluded that the thoughts of the consumers on halal food are positive.

\section{Kaynakça / References}

Abu-Hussin, M. F., Johari, F., Hehsan, A., and Mohd Nawawi, M. S. A. B. (2017). Halal purchase intention among the Singaporean Muslim minority. Journal of Food Products Marketing, 23(7), 769-782. Doi: $10.1080 / 10454446.2016 .1141139$

Ahmadova, E. and Aliyev, K. (2020). Determinants of attitudes towards Halal products. Journal of Islamic Marketing, 12(1), 55-69. Doi 10.1108/JIMA-04-2019-0068

Ajzen, I. (1991). The theory of planned behavior. Organizational behavior and human decision processes, 50(2),179-211. Erişim adresi: https://www.tandfonline.com/doi/pdf/10.1080/08870446.2011.613995

Aka, B. (2017). Bebek patlaması, X ve $Y$ kuşağı yöneticilerin örgütsel bağlılık düzeylerinin kamu ve özel sektör farklılıklarına göre incelenmesi: Bir araştırma. Süleyman Demirel Üniversitesi Vizyoner Dergisi, 9(20), 118-135. Doi: 10.21076/vizyoner.341626

Akbulut, M. S., Daştan, Ş., Can, E., ve Sipahioğlu, O. (2020). Genç tüketicilerin helal sertifikası konusunda farkındalığı ve bunun gıda tercihi üzerine etkileri: Kayseri ili örneği. Helal ve Etik Araştırmalar Dergisi, 1(2),110-121.

Akdemir, A., Konakay, G. ve Demirkaya, H. (2013). Y kuşağının kariyer algısı, kariyer değişimi ve liderlik tarzı beklentilerinin araştırılması. Ekonomi ve Yönetim Araştırmaları Dergisi, 2(2), 11-42.

Akın, M. S. ve Okumuş, A. (2020). Shaping the consumers' attitudes towards Halal food products in Turkey. Journal of Islamic Marketing, 
Cilt. Baskı öncesi No. baskı öncesi. 1-16. Doi: 10.1108/JIMA-08-20190167

Alam, S. S. and Sayuti, N. M. (2011). Applying the Theory of Planned Behavior (TPB) in halal food purchasing. International journal of Commerce and Management, 21(1), 8-20. Doi:10.1108/10569211111111676

Ali, A., Sherwani, M., Ali, A., Ali, Z., and Sherwani, S. (2020). The moderating role of Individualism/Collectivism and Materialism: An application of the Theory of Planned Behavior (TPB) in Halal Food purchasing. Journal of Food Products Marketing, 26(9), 581-599. Doi: https://doi.org/10.1080/10454446.2020.1846148.

Asif, M., Xuhui, W., Nasiri, A., and Ayyub, S. (2018). Determinant factors influencing organic food purchase intention and the moderating role of awareness: A comparative analysis. Food Quality and Preference, 63, 144-150. Doi: http://dx.doi.org/10.1016/j.foodqual.2017.08.006.

Aşık, N. A. (2019). X ve $Z$ kuşağı tüketicilerin yiyecek tercihlerini etkileyen faktörler. Journal of Tourism and Gastronomy Studies, 7(4) ,2599-2611. Doi: 10.21325/jotags.2019.489

Awan, H. M., Siddiquei, A. N. and Haider, Z. (2015). Factors affecting Halal purchase intention evidence from Pakistan's Halal food sector. Management Research Review, 38(6), 640-660. Doi: 10.1108/MRR-01-2014-0022

Aziz, Y. A. and Chok, N. V. (2013). The role of Halal awareness, Halal certification, and marketing components in determining Halal purchase intention among non-Muslims in Malaysia: A structural equation modeling approach. Journal of International Food and Agribusiness Marketing, 25(1), 1-23. Doi: 10.1080/08974438.2013.723997

Bashir, A. M. (2019). Applying the institutional theory at the level of halal consumers: The case of Cape Town in South Africa. Journal of Food Products Marketing, 25(5), 527-548. Doi: 10.1080/10454446.2019.1607645

Başaran Alagöz, S. ve Demirel, E. (2017). Helal gıda sertifikalı ürünlerin tüketici davranışları üzerine etkisi: Konya ili üzerinde bir araştırma. Journal of Süleyman Demirel University Institute of Social Sciences, 28(3), 451-472. 
Dölekoğlu, C. Ö. ve Çelik, O. (2018). Y kuşağı tüketicilerin gıda satın alma davranışı. Kahramanmaraş Sütçü İmam Üniversitesi Tarım ve Doğa Dergisi, 21, 55-66. Doi: 10.18016/ksutarimdoga.vi.474049.

Er, F. ve Sönmez, H. (2005). Temel istatistik eğitiminde R for wındows paket programı kullanımı. Eskişehir Osmangazi Üniversitesi Mühendislik ve Mimarlik Fakültesi Dergisi, 18(2), 71-86.

Farhat, K., Aslam, W. and Sanuri, B. M. M. S. (2019). Predicting the intention of generation $\mathrm{M}$ to choose family takaful and the role of halal certification. Journal of Islamic Marketing, 10(3), 724-742. Doi: 10.1108/JIMA-12-2017-0143

Fishbein, M. and Ajzen, I. (1977). Belief, attitude, intention, and behavior: An introduction to theory and research. Journal of Business Venturing, 5, 177- I89. Doi: 0883.9026@OL\$3.50

Fox, J., Nie, Z. and Byrnes, J. (2020). Sem: Structural Equation Models. $R$ PackageVersion3.1-11. https://cran.r-project.org/package=sem (Erişim Tarihi:20.11.2020)

Göktürk, E. T. (2019). Tüketicilerin helal ürün satın alma tutumlarmnn incelenmesi: Planlı Davranış Teorisi bağlamında pilot bir araştırma. (Yüksek Lisans Tezi). Erişim adresi: https://katalog.marmara.edu.tr/veriler/yordambt/cokluortam/9F0B6 97B-350E-7B40-8680-FFC8590FBA82/10256537.pdf

https://sozluk.gov.tr/ . Helal kavramı (Aralık, 2020) Türk Dil Kurumu güncel Türkçe sözlük içinde.

Huda, (2017), World's Muslim population, The Pew Research Institute, available at: www.thoughtco. com/worlds-muslim-population2004480 (accessed 19 November 2017).

Ibrahim, H. ve Ismail, H. (2015). A generational cohort study of the relationship between religious intensity and religious assurance for the purchase of non-food products. International Journal of Economics and Financial Issues, 5, 330-334. Erişim adresi: https://search.proquest.com/docview/1701253161?pqorigsite $=$ gscholar\&fromopenview $=$ true

Izberk-Bilgin, E. ve Nakata, C. C. (2016). A new look at faith-based marketing: The global halal market. Business horizons, 59(3), 285-292. Doi: http://dx.doi.org/10.1016/j.bushor.2016.01.005 
Keskin, B. (2012). İstatistiksel güç analizi: Sosyal Bilimler alanında bir uygulama. ( Yüksek Lisans Tezi), Akdeniz Üniversitesi, Sosyal Bilimler Enstitüsü, Antalya.

Khalek, A. A. ve Ismail, S. H. S. (2015). Why are we eating halal-using the theory of planned behavior in predicting halal food consumption among generation $\mathrm{Y}$ in Malaysia. International Journal of Social Science and Humanity, 5(7), 608-612. Doi: 10.7763/IJSSH.2015.V5.526

Khan, A. and Azam, M. K. (2016). Factors influencing halal products purchase intention in India: preliminary investigation. IUP Journal of Marketing Management, 15(1), 20-35. Erişim adresi: https://search.proquest.com/docview/1771700103/fulltextPDF/906AE A2BC2B34D3BPQ/1?accountid $=16382$

Kızgın, Y. ve Özkan, B. (2014). Tüketicilerin helal gıda tüketim eğilimlerinin belirlenmesine yönelik bir çalışma. Business and management studies, An International Journal, 2(1), 18-37. Erişim adresi: http://dx.doi.org/10.15295/bmij.v2i1.62

Lada, S., Tanakinjal, G. H. and Amin, H. (2009). Predicting intention to choose halal products using theory of reasoned action. International Journal of Islamic and Middle Eastern Finance and Management, 2(1), 6676. Doi: $10.1108 / 17538390910946276$

Marmaya, N. H., Zakaria, Z. and Desa, M. N. M. (2019). Gen Y consumers' intention to purchase halal food in Malaysia: A PLS-SEM approach, Journal of Islamic Marketing, 10(3), 1003-1014. Doi: 10.1108/JIMA-08-2018-0136

Mukhtar, A., and Butt, M. M. (2012). Intention to choose Halal products: The role of religiosity. Journal of Islamic Marketing, 3(2), 108-120. Doi: $10.1108 / 17590831211232519$

Omar, K. M., Mat, N. K. N., Imhemed, G. A., and Ali, F. M. A. (2012). The direct effects of halal product actual purchase antecedents among the international Muslim consumers. American journal of economics, 2(4), 87-92. Doi: 10.5923/j.economics.20120001.20

Pradana, M., Huertas-García, R. and Marimon, F. (2020). Muslim tourists' purchase intention of halal food in Spain. Current Issues in Tourism, Bask1 öncesi No. Bask1 öncesi. 1-5. Doi: 10.1080/13683500.2020.1797647. (b). 
Pradana, M., Wardhana, A., Rubiyanti, N., Syahputra, S., and Utami, D. G. (2020). Halal food purchase intention of Muslim students in Spain: Testing the moderating effect of need-for-cognition. Journal of Islamic Marketing, Baskı öncesi No. Baskı öncesi, 1-12. Doi 10.1108/JIMA-052020-0122. (a).

Sarı, E. ve Harta, G. (2018). Kuşakların Tüketim ve satın alma davranışları üzerine bir araştırma. Uluslararası Sosyal Araştırmalar Dergisi, 11(61), 967-980.

Erişim adresi: https://sosyalarastirmalar.com/cilt11/sayi61_pdf/6iksisat_kamu_islet me_turizm/sari_emre_gozdeharta.pdf

Setiawati, L. M., Chairy, C. and Syahrivar, J. (2019). Factors affecting the intention to buy Halal Food by the millennial generation: The mediating role of attitude. DeReMa (Development Research of Management): Jurnal Manajemen, 14(2), 175-188. Doi: http://dx.doi.org/10.19166/derema.v14i2.1738.

Sevim, N., Eroglu Hall, E. and Abu-Rayya, H. M. (2016). The role of religion and acculturation in the consumer ethnocentrism of Turkish immigrants in Germany. Religions, 7(3), 29. Doi:10.3390/rel7030029

Sherwani, M., Ali, A., Ali, A., and Hussain, S. (2018). Determinants of halal meat consumption in Germany. Journal of Islamic Marketing, 9(4), 863-883.b. Doi: 10.1108/JIMA-01-2018-0009

Sherwani, M., Ali, A., Ali, A., Hussain, S., and Zadran, H. G. (2018). Determinants of muslim consumers' Halal meat consumption: applying and extending the theory of planned behavior. Journal of Food Products Marketing, 24(8), 960-981.a. Doi: 10.1080/10454446.2018.1450173

Sudarsono, H. and Nugrohowati, R. N. I. (2020). Determinants of the intention to consume halal food, cosmetics and pharmaceutical products. The Journal of Asian Finance, Economics and Business (JAFEB), 7(10), 831-841. Doi: 10.13106/jafeb.2020.vol7.no10.831

Tatlı, H., Erdem, M. ve Arpacık, M. (2017). Tüketicilerin gıda tüketiminde helal gıda farkındalığı ve tutumu: Hanehalkı reisleri üzerine bir uygulama. Organizasyon ve Yönetim Bilimleri Dergisi, 9(2), 37-53. Erişim adresi: https://dergipark.org.tr/en/download/articlefile/439980 
Tuhin, M. K. W., Miraz, M. H., Habib, M. M., and Alam, M. M. (2020). Strengthening consumers' halal buying behaviour: role of attitude, religiosity and personal norm. Journal of Islamic Marketing, Cilt. Bask1 öncesi No. Baskı öncesi.1-17. Doi: 10.1108/JIMA-07-2020-0220

Williams, K. C. ve Page, R. A. (2011). Marketing to the generations. Journal of Behavioral Studies in Business, 3(1), 37-53. Erişim adresi: https://www.researchgate.net/profile/Robert_Page3/publication/242 760064_Marketing_to_the_Generations/links/540f129d0cf2f2b29a3dd 071.pdf

Yener, D. (2011). Tüketicilerin helal sertifikalı ürünlere karşı tutumlarını etkileyen faktörler ve risk algısı. Doktora Tezi. Marmara Üniversitesi, Sosyal Bilimler Enstitüsü.

Yüksekbilgili, Z. (2016). Tüketici karar verme tarzlarının kuşaklara göre değerlendirilmesi. Electronic Journal of Social Sciences, 15(59), 13921402. Doi:10.17755/esosder.49225

Zakaria, Z., Majid, M. A., Ahmad, Z., Jusoh, Z., and Zakaria, N. Z. (2017). Influence of Halal certification on customers' purchase intention. Journal of Fundamental and Applied Sciences, 9(5), 772-787. Doi: http://dx.doi.org/10.4314/jfas.v9i5s.55

\section{Kaynakça Bilgisi / Citation Information}

Yılmaz, M. K. ve Albayrak, İ. C. (2021). Kuşakların helal gida satın alma niyetlerinin Planlı Davranış Teorisi bağlamında incelenmesi: Samsun-Köln örneği. OPUS-Uluslararası Toplum Araştırmaları Dergisi, 18(40), 2191-2220. DOI: 10.26466/opus.862678. 